\title{
TOWARD A SYNTHESIS OF THE RESOURCE-BASED VIEW \\ AND ORGANIZATIONAL ECONOMICS IN THE CONTEXT OF GRAND STRATEGIES
}

\author{
James G. Combs \\ University of Mississippi \\ University, MS \\ David J. Ketchen, Jr. \\ Louisiana State University \\ Baton Rouge, LA
}

\begin{abstract}
The resource-based view ( $R B V)$ and organizational economics $(O E)$ are influential perspectives in the field of strategic management. In essence, the RBV is concerned with the creation and deployment of resources with certain qualities whereas $O E$ is focused on efficiently monitoring operations. An important area of research where these approaches have both been employed is the choice of grand strategy. Grand strategies are the alternative ways that firms can implement an expansion of firm scope, including, for example, joint ventures and internal development. The $R B V$ and $O E$ can, because of their different emphases, lead managers toward different grand strategies. Guided by prior research, this paper develops a model suggesting that firms will generally place their resource needs before monitoring considerations and that this choice brings about the best possible performance. Propositions designed to guide subsequent empirical research are developed and implications for both theory and practice are discussed.
\end{abstract}

\section{Introduction}

Researchers have enlisted several theoretical perspectives to explain organizational actions and subsequent firm performance (e.g., Child, 1972; Hannan \& Freeman, 1977; Williamson, 1975; Wernerfelt, 1984). In recent years, two of these perspectives, the resource-based view (RBV - Wernerfelt, 1984) and organizational economics (OE - Hesterly, Liebeskind \& Zenger, 1990) have been used to explain a wide variety of organizational actions including diversification (Markides \& Williamson, 1996; Teece, 1980), the evolution of competitive advantage (Barnett, Greve \& Park, 1995; Mehra, 1996), international entry mode (Anderson \& Coughlan, 1987; Anderson \& Gatignon, 1986; Oviatt \& McDougall, 1994), vertical integration (Carney \& Gedajlovic, 1991; Mahoney, 1992; McWilliams \& Gray, 1995), and organizational structure (Masten, 1984; Russo, 1991). As several important attempts to integrate these perspectives attest, they do not consistently direct researchers and prac- 
titioners toward similar conclusions (Carney \& Gedajlovic, 1991; Mahoney \& Pandian, 1992; McWilliams \& Gray, 1995). In this paper, we examine one context - grand strategies - wherein prescriptions emanating from the RBV can contradict those from OE. Defined as strategies that increase the scope of a firm (i.e., internal development, acquisition, joint venture, long-term contracting - Pearce, 1982), grand strategies can have a profound impact on organizational performance (Koh \& Venkatraman, 1991; Lamont \& Anderson, 1985; Williamson, 1994). Thus, in order to develop a better understanding of the relationship between grand strategies and performance, we work toward an integration of RBV and OE predictions in this context.

According to the RBV, managers choose among alternative strategies based on the need to build strategically valuable resource stocks (Dierickx \& Cool, 1989). Grand strategies should be chosen to enable the firm to acquire and/or protect the unique and valuable resources needed to compete effectively (e.g., Barney, 1991; Wernerfelt, 1984). By contrast, OE states that managers respond to governance costs (Mahoney, 1992). Specifically, firms are thought to seek strategies that minimize the costs of negotiating and enforcing (i.e., governing) transactions across markets vis-a-vis internal hierarchies (Williamson, 1975; 1985). Also, the costs of monitoring and bonding agents (e.g., managers or cooperative partners) gives rise to agency costs, which are another form of governance costs the firm will wish to minimize (Jensen \& Meckling, 1976). Thus, grand strategies are chosen such that transaction and agency costs are minimized.

The potential conflict between these two approaches emanates from the dual nature of the grand strategies. On one hand, grand strategies can be viewed as a tool to help the firm gain access to important resources - that is, to overcome resource constraints (Martin \& Justis, 1993; Shane, 1996). Alternatively, grand strategies can serve as a way to minimize the cost of negotiating with organizational participants and monitoring their behavior as the firm grows (Lafontaine, 1992; Williamson, 1991). In partial reconciliation of these dual purposes, McWilliams and Gray (1995) have argued that resource-scarce firms place their resource-based needs before governance cost considerations when choosing among alternative grand strategies. Using their study as a point of departure, we build a model wherein we predict the preferred grand strategy for several resource stock-governance cost contingencies. In so doing. we explain how the variables offered by $O E$ play an important secondary role. An additional step is taken by combining the RBV and OE logic to predict performance. Finally, we offer advice to managers for achieving competitive advantage as their resource and governance conditions change.

\section{Literature Review}

The RBV and OE differ considerably in terms of the factors believed to influence managerial action and the performance consequences of such actions. Specifically, the RBV is concerned with how extant resource endowments can influence the firm's ability to grow. Furthermore, the RBV draws a 
direct link between the deployment of resources and performance. In contrast, $O E$ is centered on how managers minimize the costs of monitoring and controlling the firm's activities. The consequence of efficient governance is improved performance (Hill \& Snell, 1988; Williamson, 1994).

\section{Resource-based View}

In a seminal work that laid the foundation for business-level strategic analysis, Andrews (1965) painted a fairly balanced picture of how internal and external factors contribute to successful strategies. In the ensuing years, most research in strategic management centered on external forces; it is only in the last decade that scholars have begun to carefully examine how firm-level resource differences shape strategy and performance (Barney, 1995). At the heart of the RBV of strategy is the notion that firms act to acquire "strategically valuable" resources that can be a source of a sustainable competitive advantage (i.e., superior long-term performance) for the firm (Barney, 1991; Conner, 1991; Peteraf, 1993). Indeed, it is this link between the nature of certain resources and performance that sets the RBV apart from related theories such as resource dependency (Pfeffer \& Salancik, 1982), which is primarily concerned with the firm's efforts to protect the flow of resources between the firm and its environment.

Much of the research using the RBV attempts to describe the characteristics of strategically valuable resources that will, over time, build a sustainable advantage. Such resources must be: (1) valuable, meaning buyers are willing to purchase the resources' outputs at prices significantly above their costs, (2) rare, so that buyers cannot turn to competitors with the same (or substitute) resources, and (3) imperfectly imitable, meaning it would be difficult for competitors to either imitate or purchase the resources (Barney, 1986a; 1991; Lippman \& Rumelt, 1982; Peteraf, 1993; Reed \& DeFillippi, 1990). Some of the specific resources that may meet these conditions are management teamwork (Castanias \& Helfat, 1991; Hambrick, 1987), culture (Barney, 1986b), brand name capital (Aaker, 1991), implementation of total quality management (Powell, 1995), and trust (Barney \& Hansen, 1994).

Firms in possession of strategically valuable resources are expected to achieve superior performance. That is, resource-based differences among firms can help explain performance differences because the set of products and services that can efficiently emerge from any unique configuration of resources is itself unique. Performance differences emerge from buyer preferences, which generally favor the outputs (i.e., products and services) of some resource configurations more than others (Barney, 1991; Wernerfelt, 1984).

In addition to the strategically valuable resources that underlie competitive advantage, firms must also have access to any "complementary" resources that are necessary to bring products or services to market (Barney, 1995; Teece, 1987). For example, a superior design is of little use without access to the manufacturing and distribution facilities necessary to reach buyers. When complemen- 
tary resources are lacking, products cannot be provided to markets and returns to strategic resources cannot be realized (Mahoney \& Pandian, 1992). Thus, both strategic and complementary resources are important components of the firm's endowments (Barney, 1995).

Because resources are closely linked to performance, managerial action is, according to the RBV, directed primarily toward building strategically valuable resources. However, these resources can take considerable time to develop (Dierickx \& Cool, 1989). As Penrose (1959) explained, the time it takes to hire and develop experienced and committed managers can slow organizational expansion; growth must be put on hold until a cadre of capable managers can emerge. Other resource-building efforts such as the development of organizational routines (Nelson \& Winter, 1982; Shane, 1996), the building of a reputation (Dierickx \& Cool, 1989) and access to a pool of capital (Martin \& Justis, 1993) have also been shown to affect organizational growth rates. Thus, resources can influence managerial action by compelling managers to find ways to delimit their resource-based constraints (Mahoney \& Pandian, 1992). One common solution is to invoke a grand strategy that involves cooperation with an external organization so that the firm can grow with the aid of the other's resources (Erramilli \& Rao, 1990; Harrigan, 1985; Ingham \& Thompson, 1994; Teece, 1987). Indeed, because firms can often perform activities in cooperation that neither could perform independently (Erramilli \& Rao, 1990; Hamel, 1991), resource sharing has become a primary explanation for many forms of cooperation (Borys \& Jemison, 1989).

\section{Organizational Economics}

Transaction cost economics and agency theory constitute the two major theories supporting OE (Barney \& Ouchi, 1986; Hesterly et al., 1990). Transaction cost asserts that firms choose strategy so that organizational activities are performed in the least cost environment - hierarchy or market (i.e., whether to internalize a function or contract for it with an external actor - Williamson, 1975). Transaction cost economics can trace its roots to the work of Coase (1937). By recognizing the costs inherent in using markets to perform transactions, Coase hypothesized that firms will grow until the marginal costs of organizing equals the marginal costs of contracting in markets. Williamson (1975) extended this logic by articulating market and transaction specific variables that may influence a firm's choice between hierarchy and market. In general, as a firm becomes interdependent with another, it increases its exposure to potential opportunistic behavior on the part of the other firm. Risk of opportunism is thus a cost that encourages firms to internalize activities otherwise performed by external organizations (Williamson, 1975).

For transaction cost economics, the pivotal variable affecting governance costs is the specificity of assets deployed in the performance of organizational activities (e.g., Dyer, 1996; Teece, 1980; 1987). Asset specificity refers to the 
difficulty of redeploying assets to alternative uses without sacrificing their productive value (Williamson, 1991). Essentially, because highly specific assets cannot be easily used for other purposes, they render those who have invested in them dependent on the participants charged with employing them. If participants take advantage of the firm, expected profits from investments in specific assets would be lost. Thus, if the firm must invest in specific assets, it will seek to control those resources as tightly as possible - usually through direct ownership (Anderson \& Gatignon, 1986; Williamson, 1985; 1991).

Agency theory is the second dominant perspective comprising OE. It is focused on the relationship between principals and their agents - to whom some decision making authority is delegated (Eisenhardt, 1989; Jensen \& Meckling, 1976). Agency theory was developed in the 1960s and 1970s by economists studying how groups could be efficiently monitored given group members' incentive to shirk (e.g., Alchian \& Demsetz, 1972). Because principals and agents are assumed to have divergent self-interests, the central premise of agency theory states that they will jointly minimize: (1) the principal's costs of monitoring the agent's actions, (2) any costs paid by the agent to ensure the principal's interests (i.e., bonding costs), and (3) any residual loss due to remaining divergence between their respective goals (Jensen \& Meckling, 1976).

A key agency variable is the task programmability of organizational participants' responsibilities (Gomez-Mejia \& Balkin, 1992; Mahoney, 1992; Stroh, Brett, Baumann \& Reilly, 1996). The cost of monitoring participants' behavior directly is lower when job tasks can be easily specified in advance. Thus, hierarchical relationships between participants are likely when task programmability is high. In contrast, task ambiguity and other impediments to the gathering of meaningful information about participants' job performance - such as geographic distance (e.g., Brickley \& Dark, 1987) or cultural differences (e.g., Roth \& O'Donnell, 1996) - can raise the costs of monitoring within the hierarchy. In these conditions, it is often less costly to contract for products and services from agents outside the firm (e.g., Lafontaine, 1992; Mahoney, 1992).

Although they do not share the same academic legacy, the two theories that compose the OE perspective have some notable similarities. Both possess an efficiency orientation that offers guidance for selecting among alternative grand strategies. Moreover, as depicted in Table 1, they share many of the same assumptions and emphasize many of the same independent variables (Hesterly et al., 1990).

Indeed, Mahoney (1992) showed that by including both ex ante information search and negotiation costs, as well as ex post monitoring, bonding, and adaptation costs, transaction cost simply encompasses a broader array of governance cost variables into its framework. Hence, agency costs can be viewed as a sub-set of transaction costs. The theories' central differences are found in their units of analysis and dependent variables. Transaction cost economics is generally used to analyze governance relationships between organizational units whereas agency 
Table 1

Similarities and Differences between the Primary Theories of Organizational Economics'

\begin{tabular}{|c|c|c|}
\hline Dimension & Transaction Costs & Agency Theory \\
\hline Focus & Organizational Boundary & $\begin{array}{l}\text { Principal-Agent } \\
\text { Relationship }\end{array}$ \\
\hline Unit of Analysis & Transaction & Contract \\
\hline Dependent Variable & $\begin{array}{l}\text { Organizational } \\
\text { Governance } \\
\text { (i.e., Market v. Hierarchy) }\end{array}$ & $\begin{array}{l}\text { Agent Governance } \\
\text { (i.e., Behavior-based v. } \\
\text { Outcome-based Contracts) }\end{array}$ \\
\hline Independent Variables & $\begin{array}{l}\text { Asset Specificity } \\
\text { Uncertainty/Complexity } \\
\text { Transaction Frequency } \\
\text { Number of Buyers/Sellers }\end{array}$ & $\begin{array}{l}\text { Risk Propensities } \\
\text { Uncertainty } \\
\text { Task Programmability } \\
\text { Information Asymmetry }\end{array}$ \\
\hline Assumptions & $\begin{array}{l}\text { Self Interest } \\
\text { Goal Conflict } \\
\text { Bounded Rationality } \\
\text { Information Asymmetry } \\
\text { Efficiency Motive }\end{array}$ & $\begin{array}{l}\text { Self Interest } \\
\text { Goal Conflict } \\
\text { Bounded Rationality } \\
\text { Information Asymmetry } \\
\text { Efficiency Motive } \\
\text { Risk Aversion }\end{array}$ \\
\hline Central Governance Costs & $\begin{array}{l}\text { expost: } \\
\text { Monitoring } \\
\text { Bonding } \\
\text { Maladaptation Loss } \\
\text { Adaptation Costs }\end{array}$ & $\begin{array}{l}\text { ex post: } \\
\text { Monitoring } \\
\text { Bonding } \\
\text { Adaptation Loss } \\
\text { Maladaptation Loss }\end{array}$ \\
\hline
\end{tabular}

${ }^{1}$ This Table draws heavily from Eisenhardt (1989), Mahoney (1992), and Williamson (1975; 1985).

theory emphasizes the relation between the firm (as principal) and individual actors (as agents). As a result, transaction cost analysis economics is generally used to investigate grand strategies where key individual actors are sometimes difficult to isolate (e.g., acquisition, joint ventures) while agency theory is used to investigate strategies where principal-agent dyads are clear (e.g., long term contracts). Because the grand strategies represent alternative ways to organize the firm's activities, both theories are needed to explain the choice of grand strategy along the entire range of alternatives. Thus, following others who have drawn from the OE perspective (e.g., Barney \& Ouchi, 1986; Hesterly et al., 1990), we 
emphasize transaction cost economics' and agency theory's common concern for efficiency and treat them as complementary.

\section{Toward an Integration of Perspectives}

In recent years, several articles have incorporated ideas from both the RBV and OE (e.g., Bergh, 1995; Carney \& Gedajlovic, 1991; Conner, 1991; Mahoney \& Pandian, 1992; McWilliams \& Gray, 1995). Broadly speaking, three identifiable patterns can be seen in the literature that help define how the RBV and OE approaches might be related. First, they can be viewed as independent explanations in which only one perspective is considered to explain a particular phenomenon with little consideration of the other. For example, much of the vertical integration literature (e.g., Masten, 1984; Monteverde \& Teece, 1992; Walker \& Weber, 1984; see Argyres, 1996 for a recent exception) and the international entry mode literature is grounded in OE (e.g., Anderson \& Coughlan, 1987; Anderson \& Gatignon, 1986; see Oviatt $\&$ McDougall, 1994 for a recent exception), whereas the evolution of competitive advantage is usually grounded in the RBV (e.g., Barnett, Greve \& Park, 1995; Levinthal \& Myatt, 1995).

A second approach is to envision these perspectives as complementary, each offering insights that generally point managers and researchers in similar directions. The complementary view is, in part, found in the recognition that specific assets share an important quality with strategically valuable resources (e.g., Amit \& Schoemaker, 1993; Dyer, 1996). That is, specific assets are difficult to trade (Chi, 1994), which is one of the conditions needed for a set of resources to meet the definition of strategically valuable (Peteraf, 1993). This commonality explains why greater performance among firms with certain diversification postures can either be explained as the product of an efficient (i.e., governance cost minimizing) way to organize activities (e.g., Hill, Hitt \& Hoskisson, 1992; Teece, 1980) or a strategy for exploiting strategically valuable resources in new markets (e.g. Chatterjee \& Wernerfelt, 1991; Markides \& Williamson, 1996; Prahalad \& Hamel, 1990; Robins \& Wiersema, 1995). In their examination of vertical integration, McWilliams and Gray (1995) have addressed a third view - the relationship can be conflictive. This can occur when managerial action is directed toward delimiting resource constraints while governance conditions point elsewhere. Grand strategies offer a context in which to study this managerial dilemma.

\section{Grand Strategies}

Grand strategies refer to the alternative ways that firms can expand their scope (Pearce, 1982). Although each contains numerous variations, grand strategies can generally be categorized into four basic groups - internal development, acquisition, joint venture, and long-term contracting (Anderson \& Gatignon, 1986; Erramilli \& Rao, 1990). Firms engaged in internal development supply all 
necessary resources and control operations by extending their hierarchy (Barney, 1988; Chatterjee, 1990). Acquisitions involve the transfer of control from a previous set of owners to a new one (Borys \& Jemison, 1989). A joint venture is a new organization is that is supported and controlled by two "parent" organizations (Harrigan, 1985; Koh \& Venkatraman, 1991). Under long-term contracting, cooperating firms do not create a third entity. Such arrangements are generally held together by the legal system (Williamson, 1991), often with the aid of credible commitments by participants (Teece, 1987).

Grand strategies are fundamental to business growth and have been studied in the context of diversification entry mode (e.g., Chatterjee, 1990; Yip, 1982), vertical integration (e.g., Carney \& Gedajlovic, 1991; McWilliams \& Gray, 1995), and geographic (primarily international) expansion (e.g., Anderson \& Gatignon, 1986; Hill, Hwang \& Kim, 1990). As shown in Table 2, the choice of grand strategy can reflect a response to either resource demands or governance conditions. Thus, the grand strategies open a window into the potential conflict between the RBV and OE because they contain both a resource and a governance element. From the RBV, alternative expansion modes make different resource demands on the firm. Internal development and acquisition demand that the firm supply all of the strategic and complementary resources needed to successfully implement an expansion effort (cf. Barney, 1988; Chatterjee, 1990). Joint ventures and long-term contracts, in contrast, permit the firm to share its resource burden with external partners (Borys \& Jemison, 1989; Oviatt \& McDougall, 1994). Thus, the latter offer means to overcome resource-based constraints to growth (Erramilli \& Rao, 1990; Ingham \& Thompson, 1994; Teece, 1987).

Grand strategies also serve as alternative arrangements for governance. That is, they are different methods for governing the behavior of organizational actors, each imbued with different governance cost incentives and penalties (e.g., Anderson \& Gatignon, 1986; Lafontaine, 1992; Williamson, 1991; 1994). Specifically, internal development and acquisition offer greater control over organizational participants because behavior can be monitored directly. The employment contract gives firms significant latitude to replace organizational participants who are not acting in the firm's best interests (Williamson, 1991). When there are considerable incentives for an external partner to act opportunistically (e.g., because of the programmability of the work and/or specificity of assets involved), these grand strategies offer the tools to offset such risks. Conditions that might foster opportunism among external partners are labeled here as high cost of external governance.

The behavioral controls offered by internal development and acquisitions, however, must be balanced against inefficiencies and inflexibility that can result from the larger bureaucracy created by these strategies (i.e., bureaucratic costs Jones \& Hill, 1988; Merton, 1945). Long-term contracting and joint ventures, in contrast, can offer increased flexibility and efficiency because firms only pay for needed products or services. Thus, when the risks of opportunistic behavior on 
Table 2

Grand Strategies Juxtaposed Against Resource-based and Organizational Economics Criteria

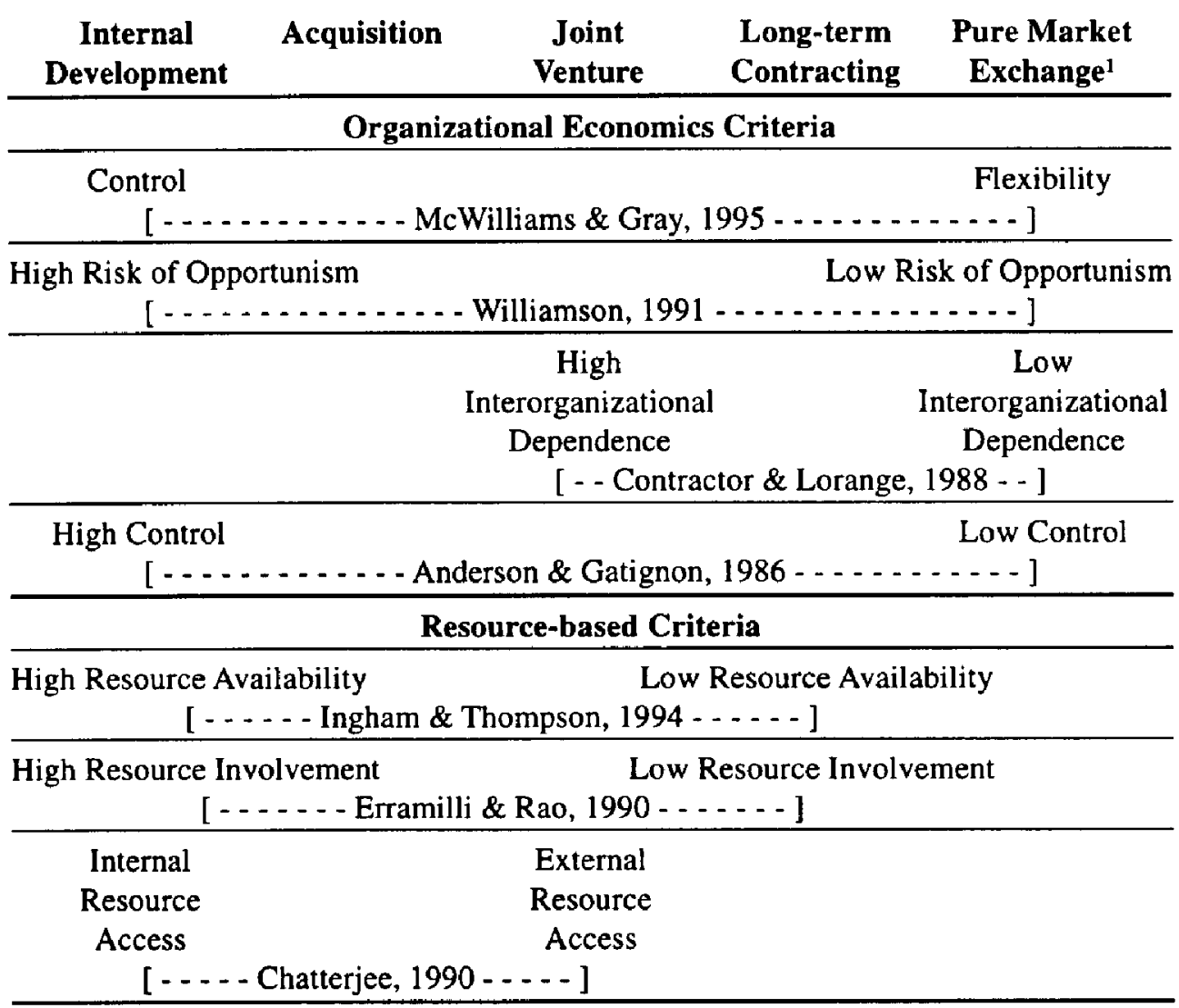

'Pure market exchange is not considered a grand strategy because the firm has not increased the scope of its operations.

the part of an external partner is low, the firm will prefer to cooperate. These conditions are labeled here as low cost of external governance.

\section{Propositions}

Figure 1 presents a model that integrates the RBV and $O E$ in the context of grand strategy. In the model, strategy is influenced jointly by resource and governance conditions. The grand strategies, in turn, affect performance directly. 
Figure 1

An Integrative Model of Grand Strategy and Performance

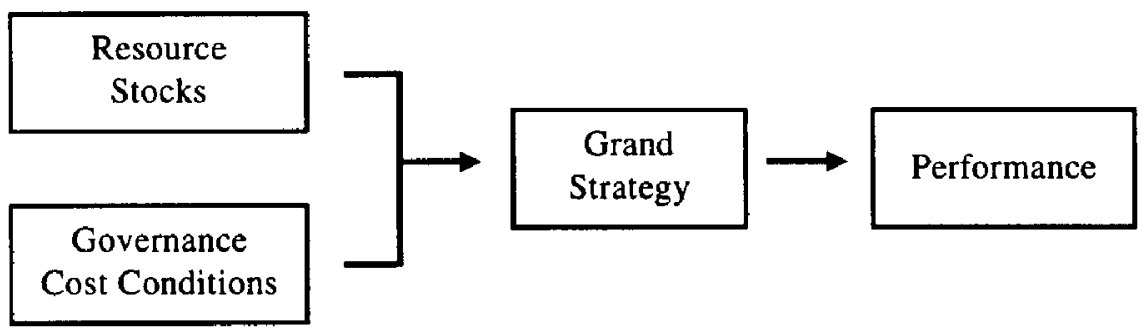

\section{Effects of Resource Stocks and Governance Cost Conditions on Strategy}

The potential conflict between the RBV and OE occurs when the firm's resourceversus governance-based contingencies push the firm toward different grand strategies (cf. Carney \& Gedajlovic, 1991; McWilliams \& Gray, 1995). Specifically, what is a firm to do when it does not have access to the resource stocks necessary to use the governance cost minimizing strategy? Such firms either have to cooperate with an external firm that can help delimit resource constraints or forego expansion opportunities. Because cooperative strategies such as joint ventures and long-term contracts best delimit resource constraints by permitting independent firms to cooperate, these will be preferred when resource stocks are insufficient to permit the firm to achieve its growth objective independently (Ingham \& Thompson, 1994). Resource constrained firms simply have no alternative but to grow through long-term contracting or joint ventures, even when these are not the most efficient governance arrangements (McWilliams \& Gray, 1995). If the resource stocks that are missing can be furnished by an external partner with little risk of opportunism, then the firm will take advantage of this low cost of external governance situation by contracting. Thus, it is predicted that:

Proposition 1: When firms possess insufficient resource stocks under low cost of external governance, long-term contracts will be preferred.

Conversely, when needed resources cannot be easily contracted for without considerable exposure to potential opportunism, joint ventures become the only viable option. The governance costs of contracting can be high because the firm must expose its strategically valuable resources to the external firm in order to create a configuration of resources sufficient for existing opportunities. Under a long-term contract, the firm risks creating a competitor if its partner can, over time, imitate the firm's strategically valuable resources. Similarly, there is considerable risk that after highly specific investments have been made by the firm, the partner could demand to renegotiate their contract as a condition for contin- 
ued cooperation. The advantage of a joint venture is that both firms must make a credible commitment to the venture (Hennart, 1988; Teece, 1987). Because each partner must expose its resources to potential loss, gains from opportunistic behavior are reduced. Accordingly, we expect:

Proposition 2: When firms possess insufficient resource stocks under high cost of external governance, joint ventures will be preferred.

When firms possess adequate resource stocks, the need to use strategy for resource accumulation is eliminated. Hence, strategic choices will reflect minimization of governance costs. As McWilliams and Gray (1995) pointed out, firms that possess a complete set of strategically valuable resources have an incentive to control these resources tightly through company ownership because they are the source of above average returns. Thus, resource-abundant firms can be expected to grow primarily through the grand strategies of internal development and acquisition. However, if the strategically valuable resources must be combined with complementary resources that can be contracted for at competitive prices and with little risk of opportunism then there is room for cooperation (Mahoney \& Pandian, 1992; Teece, 1987). Under these low costs of external governance conditions, there is no reason for the firm to endure the bureaucratic costs and loss of flexibility that may accompany the internal development or acquisition of complementary assets. For example, a clothing designer may earn higher returns and increase flexibility by contracting for manufacturing and distribution activities. Thus, when strategically valuable resources are sufficient, but the cost of external governance remains low, we expect firms to contract for any activities that are not central to their competitive advantage. Stated formally:

Proposition 3: When firms possess sufficient stocks of strategically valuable resources under low cost of external governance, they will prefer internal development or acquisition for those activities that depend on strategically valuable resources and long-term contracts for activities that depend on complementary resources.

Occasions also exist in which complementary activities must be so tightly linked to strategically valuable activities that it would be difficult for them to be conducted in different firms because of the risk of opportunism (e.g., sales and manufacturing of industrial products - Anderson \& Coughlan, 1987). When the firm is relatively resource rich, it has no incentive to expose its anticipated income stream to opportunistic behavior from external firms (McWilliams \& Gray, 1995) and will thus engage new opportunities through internal development or acquisition. Stated formally: 
Proposition 4: When firms possess sufficient stocks of strategically valuable resources under high cost of external governance, they will prefer internal development and/or acquisition.

The four propositions above are visually depicted in Figure 2.

Figure 2

Proposed Integration of Resource Stock and

Governance Cost Effects on Grand Strategy

\begin{tabular}{|c|c|c|c|}
\hline & & Resou & cks \\
\hline & & Sufficient & Insufficient \\
\hline & High & $\begin{array}{l}\text { Internal Development } \\
\text { and/or Acquisition }\end{array}$ & Joint Venture \\
\hline Governance & Low & $\begin{array}{l}\text { Internal Development } \\
\text { and/or Acquisition } \\
\text { and } \\
\text { Long-term } \\
\text { Contracting }\end{array}$ & $\begin{array}{l}\text { Long-term } \\
\text { Contracting }\end{array}$ \\
\hline
\end{tabular}

The distinction between internal development and acquisition depends on the firm's current configuration of resources (Chatterjee, 1990; Yip, 1982). If existing resource stocks can be employed in the new market, internal development is preferred. This might occur, for example, for brand extensions or geographic growth. However, if the configuration of resources needed to engage the target market differ considerably from existing resource stocks, acquisition is likely to be used to access needed resources. Such would likely be the case for some types of diversification. Thus, we offer the following corollaries to propositions 3 and 4 :

Corollary 1: Firms with sufficient stocks of strategically valuable resources will prefer internal development when the new activity is an extension of current resources.

Corollary 2: Firms with sufficient stocks of strategically valuable resources will prefer acquisition when the new activity requires a new configuration of resources. 


\section{Grand Strategy and Performance}

Because a distinguishing characteristic of strategic management research is its emphasis on performance (Summer et al., 1990; Venkatraman \& Ramanujam, 1986), it is not enough to specify the influence of resource stocks and governance costs on grand strategy. Unless there are implications for performance, the value of matching strategy to resource and governance conditions is limited. Above it was suggested that long-term competitive success rests first on the firm's capacity to access and exploit strategically valuable resources. It was predicted that when firms possess few of these resources, they will be prompted to engage in joint ventures and long-term contracting to gain the use of resources, even if governance cost conditions might predict otherwise. However, firms will still consider their governance cost conditions when selecting between joint ventures and long-term contracts. Specifically, when high external governance costs conditions make cooperation potentially costly, firms will favor joint ventures. The expectation that governance cost will impact performance through strategy is based, in part, on the efficiency logic that underlies OE (Barney \& Ouchi, 1986; Hesterly et al., 1990). That is, by responding appropriately to governance cost pressures, firms are selecting low cost alternatives. Presumably, choosing the "correct" (i.e., low cost) strategy translates into better performance (Hill \& Snell, 1988; Williamson, 1994). Taken together, we expect the following propositions to hold true:

Proposition 5: Firmts that engage in long-term contracting when their resource stocks are insufficient and their cost of external governance is low will perform better than firms that use other grand strategies under these conditions.

Proposition 6: Firms that engage in joint ventures when their resource stocks are insufficient and their cost of external governance is high will perform better than firms that use other grand strategies under these conditions.

When stocks of strategically valuable resources are sufficient, firms are expected to defer to $O E$ concerns when selecting grand strategy. Nevertheless, firms can increase their strategic flexibility and minimize bureaucratic costs by contracting for complementary activities when the cost of external governance is low. This additional efficiency should translate into improved performance. Accordingly:

Proposition 7: Firms that engage in the internal development or acquisition of strategically valuable resources and long-term contracting for complementary resources when resource stocks 
are sufficient and the cost of external governance is low will perform better than firms that use other grand strategies under these conditions.

The luxury of contracting complementary activities is not efficient when the costs of external governance are high. The risk of opportunistic behavior is simply too severe considering the firm can access all needed resources internally. Thus, we expect that:

\section{Proposition 8: Firms that engage in internal development or acquisition when stocks of strategically valuable resources are sufficient and the cost of external governance is high will per- form better than firms that use other grand strategies under these conditions.}

\section{Discussion}

Several implications can be drawn for research and practice from our synthesis of RBV and $\mathrm{OE}$ insights into grand strategies. For researchers, it appears that both perspectives are needed to fully explain choices among grand strategies. If so, empirical investigations that recognize both perspectives should enjoy greater predictive power than existing models. For practitioners, this integration offers guidance for selecting among grand strategies. Specifically, the trade-offs in responding to resource versus governance contingencies may have an impact on performance. Below we suggest that the nature of this trade-off changes as the firm grows and matures.

\section{Implications for Research}

The logic developed above indicates that the relationship between resource stocks and grand strategy depends on governance costs and the relationship between governance costs and grand strategy depends on resource stocks. The implication is that prior research examining any of the grand strategies from one perspective without consideration of the other should be viewed cautiously. Likewise, future scholars focused on either resource stocks or governance costs should include measures of the other, at least as control variables, or they will face the risk of having an underspecified empirical model.

Indeed, models that include both RBV and $O E$ variables should have enhanced predictive power because more fully specified models have greater potential to explain variance. Increased predictive power is important to managers who need to better predict competitors' behavior and to researchers who wish to use these models to better understand the link between strategy and performance. Although our solution to the conflict between the RBV and OE in the context of grand strategies is consistent with each perspective's prior empirical 
results, little has been done empirically to compare the joint effects of resources and governance conditions on grand strategy. Examining these relationships in more detail will be an important next step for future inquiry.

In this paper, we have examined $\mathrm{RBV}$ and $\mathrm{OE}$ prescriptions regarding grand strategies without challenging any of the fundamental assumptions that underlie either perspective. Thus, another potentially fruitful avenue of research may be to relax key theoretical assumptions (Barney, 1990). Indeed, an important body of literature has emerged contradicting $\mathrm{OE}$ assumptions concerning the rational self-interested behavior of organizational participants (e.g., Donaldson, 1990; Moran, 1996). This research argues that organizational participants are, as often as not, trustworthy. That is, participants will act according to generally accepted ethical principles even when it is not in their rational self-interest to do so (Hosmer, 1995). Extant research suggests that the need for formal governance arrangements are diminished when a climate of trust prevails (Chiles \& McMackin, 1996; Granovetter, 1985; Ouchi, 1980). Moreover, because trust may diminish the need for expensive formal governance arrangements, it can be viewed as a strategically valuable resource (Barney \& Hansen, 1994). Although it may be difficult to tease out behaviors based in trust versus self-interest, such an effort might give researchers insight into the extent to which trust affects the choice of grand strategy. Future research could also benefit from increased understanding of the social and psychological antecedents of trust (Granovetter, 1985; Mayer, Davis \& Schoorman, 1995).

\section{Managerial Implications}

The ideas developed in this paper have important implications for managers as well. Modern organizations are forced to confront a staggering array of challenges, including rapid advances in information technology (Fulk \& DeSanctis, 1995), the emergence of new organizational forms (Miles \& Snow, 1994), and the globalization of many markets (Chang, 1995). Under such conditions, understanding the relationship between strategy and performance is of great practical interest. Indeed, a well-constructed strategy is one of the few weapons managers have available to help ensure the viability of the organization.

Building on prior research, this paper suggests that managers give resource issues primacy over governance concerns in grand strategy decisions. This was based on evidence from the RBV suggesting that deployment of strategically valuable resources is central to performance. Nevertheless, as the OE perspective points out, there is an efficiency loss when firms must cooperate with others through, for example, a joint venture to gain access to valuable resources when governance conditions dictate otherwise. Although accessing a partner's strategically valuable resources may enhance performance, the apparent loss of efficiency might be expected to reduce profits vis-a-vis a competitor owning all needed resources.

In time, however, the firm possesses two avenues for recovering this efficiency loss. First, trust between the firm and its joint venture partner can be built, 
which may negate the need for formal hierarchical governance (Barney \& Hansen, 1994). Second, the firm could use the joint venture to, over time, develop its own endowments and either acquire or shutdown its joint venture operations (Hamel, 1991). Under either scenario, the firm suffers a small short-term inefficiency in order to capitalize on strategically valuable resources over the long-term.

Overall, managers are encouraged to view increased deployment of strategically valuable resources as sources of increased revenue. Their second concern should be to manage these resources as efficiently as possible with an eye toward building future resources. Managers must be aware that this prioritization may require short-term inefficiencies as a price for enhanced long-term performance.

\section{Conclusion}

The RBV and OE are increasingly popular views of organizational action. In the context of grand strategies, these views do not always point managers in the same direction. We have taken a step toward reconciliation of these views and drawn a link between resource- versus governance-based antecedent conditions, strategy and performance. Future inquiry into grand strategies may enjoy greater predictive power by recognizing the contributions of each perspective. More importantly, managers can use insights from both views to better understand potential trade-offs and their impact on firm performance.

\section{References}

Aaker, D. (1991). Managing brand equity: Capitalizing on the value of brand name. New York: Free Press.

Alchian, A. A., \& Demsetz, H. (1972). Production, information costs, and economic organization. American Economic Review, 62. 777-794.

Amit, R., \& Schoemaker, P. (1993). Strategic assets and organizational rent. Strategic Management Joumal. 14, 33-46.

Anderson, E., \& Coughlan, A. T. (1987, January). International market entry and expansion via independent or integrated channels of distribution. Journal of Marketing 51. $71-82$.

Anderson, E., \& Gatignon, H. (1986). Modes of foreign entry: A transaction cost analysis and propositions. Journal of International Business Studies, 17, 1-26.

Andrews, K. R. (1965). The concept of corporate strategy. Homewood, IL: Irwin.

Argyres, N. (1996). Evidence on the role of firm capabilities in vertical integration decisions. Strategic Management Journal 17, 129-150. 
Barnett, W. P., Greve, H. R., \& Park, D. Y. (1995). An evolutionary model of organizational performance. Strategic Management Journal. 15, 11-28.

Barney, J. B. (1986a). Strategic factor markets: Expectations, luck, and business strategy. Management Science. 32, 1231-1241.

Barney, J. B. (1986b). Organization culture: Can it be a source of sustained competitive advantage? Academy of Management Review, 11, 656-665.

Barney, J. B. (1988). Returns to bidding firms in mergers and acquisitions: Reconsidering the relatedness hypothesis. Strategic Management Journal. 9, 71-78.

Barney, J. B. (1990). The debate between traditional management theory and organizational economics: Substantive differences or intergroup conflict? Academy of Management Review, 15, 382-393.

Barney, J.B. (1991). Firm resources and sustained competitive advantage, Journal of Management, 17, 99-120.

Barney, J. B. (1995). Looking inside for competitive advantage. Academy of Management Executive. 9, 49-61.

Barney, J. B., \& Hansen, M. H. (1994). Trustworthiness as a source of competitive advantage. Strategic Management Journal. 15, 175-190.

Barney, J. B., \& Ouchi, W. G. (1986). Organizational economics: Toward a new paradigm for understanding and studying organizations. San Francisco: Jossey-Bass.

Bergh, D. D. (1995). Size and relatedness of units sold: An agency theory and resourcebased perspective. Strategic Management Journal. 16, 221-240.

Borys, B., \& Jemison, D. B. (1989). Hybrid arrangements as strategic alliances: Theoretical issues in organizational combinations. Academy of Management Review. 14, 234249.

Brickley, J. A., \& Dark, F. H. (1987). The choice of organizational form: The case of franchising. Journal of Financial Economics. 18, 401-420.

Carney, M., \& Gedajlovic, E. (1991). Vertical integration in franchise systems: Agency theory and resource explanations. Strategic Management Journal. 12, 607-629.

Castanias, R. P., \& Helfat, C. E. (1991). Managerial resources and rents. Journal of Management. 17, 155-172.

Chang, S. J. (1995). International expansion strategy of Japanese firms: Capability building through sequential entry. Academy of Management Journal. 38, 383-407. 
Chatterjee, S. (1990). Excess resources, utilization costs, and mode of entry. Academy of Management Journal, 33, 780-800.

Chatterjee, S., \& Wernerfelt, B. (1991). The link between resources and type of diversification: Theory and evidence. Strategic Management Journal, 12, 33-48.

Chi, T. (1994). Trading in strategic resources: Necessary conditions, transaction cost problems, and choice of exchange structure. Strategic Management Journal. 15, 271-290.

Child, J. (1972). Organizational structure, environment and performance: The role of strategic choice. Sociology, 6, 1-22.

Chiles, T. H., \& McMackin, J. F. (1996). Integrating variable risk preferences, trust, and transaction costs economics. Academy of Management Journal, 21, 73-99.

Coase, R. H. (1937). The nature of the firm. Econometrica, 4, 386-405.

Conner, K. R. (1991). A historical comparison of resource based theory and five schools of thought within industrial organization economics: Do we have a new theory of the firm? Journal of Management, 17 , 121-154.

Contractor, F. J., \& Lorange, P. (1988). Why should firms cooperate? The strategy and economics basis for cooperative ventures. In F. J. Contractor \& P. Lorange (Eds.), Cooperative strategies in international business (pp 3-30). Lexington, MA: Lexington.

Dierickx, I., \& Cool, K. (1989). Asset stock accumulation and sustainability of competitive advantage. Management Science, 35, 1504-1514.

Donaldson, L. (1990). The ethereal hand: Organizational economics and management theory. Academy of Management Review, 15, 369-381.

Dyer, J. H. (1996). Specialized supplier networks as a source of competitive advantage: Evidence from the auto industry. Strategic Management Journal. 17, 271-292.

Eisenhardt, K.M. (1989). Agency theory: An assessment and review. Academy of Management Review, 14, 57-74.

Erramilli, M. K., \& Rao, C. P. (1990). Choice of foreign market entry modes by service firms: Role of market knowledge. Management International Review, 30, 135-150.

Fulk, J., \& DeSanctis, G. (1995). Electronic communication and changing organizational forms. Organization Science, 6, 337-349.

Ghoshal, S. \& Moran, P. (1996). Bad for practice: A critique of the transaction cost theory. Academy of Management Review, 21, 13-47. 
Gomez-Mejia, L. A., \& Balkin, D. B. (1992). Determinants of faculty pay: An agency theory perspective. Academy of Management Journal, 35, 921-955.

Granovetter, M. (1985). Economic action and social structure: The problem of embeddedness. American Journal of Sociology, 91, 481-510.

Hambrick, D. C. (1987). The top management team: A key to strategic success. California Management Review, 30, 88-108.

Hamel, G. (1991). Competition for competence and inter-partner learning within international strategic alliances. Strategic Management Journal, 12, 83-103.

Hannan, M. T. \& Freeman, J. H. (1977). The population ecology of organizations. American Journal of Sociology, 82, 929-964.

Harrigan, K. (1985). Joint ventures and competitive strategy. Strategic Management Journal, $9,141-158$.

Hennart, J. F. (1988). A transaction costs theory of equity joint ventures. Strategic Management Joumal, $9,361-374$.

Hesterly, W. S., Liebeskind, J., \& Zenger, T. R. (1990). Organizational economics: An impending revolution in organization theory? Academy of Management Review. 15 , $402-420$.

Hill, C. W. L., Hitt, M. A., \& Hoskisson, R. E. (1992). Cooperative versus competitive structures in related and unrelated diversified firms. Organization Science, 3, 501521.

Hill, C. W. L., Hwang, P., \& Kim, C. W. (1990). An eclectic theory of the choice of international entry mode. Strategic Management Journal. 11, 117-128.

Hill, C. W. L., \& Snell, S. (1988). External control, corporate strategy, and firm performance in research-intensive industries. Strategic Management Journal, 9, 577-590.

Hosmer, L. T. (1995). Trust: The connecting link between organizational theory and philosophical ethics. Academy of Management Review, 20, 379-403.

Ingham, H., S., \& Thompson, S. (1994). Wholly-owned versus collaborative ventures for diversifying financial services. Strategic Management Journal, 15, 325-334.

Jensen, M. C., \& Meckling, W. (1976). Theory of the firm: Managerial behavior, agency costs, and ownership structure. The Journal of Financial Economics, 3, 305-360.

Jones, G. R., \& Hill, C. W. L. (1988). Transaction cost analysis of strategy-structure choice. Strategic Management Joumal, 9, 159-172. 
Koh, J., \& Venkatraman, N. (1991). Joint venture formations and stock market reactions: An assessment in the information technology sector. Academy of Management Journal. 34, 869-892.

Lafontaine, F. (1992). Agency theory and franchising: Some empirical results. RAND Journal of Economics. 23, 263-283.

Lamont, B. T., \& Anderson, C. R. (1985). Mode of corporate diversification and economic performance. Academy of Management Journal. 28, 926-934.

Levinthal, D., \& Myatt, J. (1995). Co-evolution of capabilities and industry: The evolution of mutual fund processing. Strategic Management Journal. 15, 45-62.

Lippman, S. A., \& Rumelt, R. P. (1982). Uncertain imitability: An analysis of interfirm differences in efficiency under competition. Bell Journal of Economics. 13, 418-453.

Mahoney, J. T. (1992). The choice of organizational form: Vertical financial ownership versus other methods of vertical integration. Strategic Management Journal. 13, 559584.

Mahoney, J. T., \& Pandian, J. R. (1992). The resource-based view within the conversation of strategic management. Strategic Management Journal. 13, 363-380.

Markides, C. C., \& Williamson, P. J. (1996). Corporate diversification and organization structure: A resource-based view. Academy of Management Journal. 39, 340-367.

Martin, R. E., \& Justis, R. T. (1993). Franchising, liquidity constraints and entry. Applied Economics, 25, 1269-1277.

Masten, S. E. (1984). The organization of production: Evidence from the aerospace industry. Journal of Law and Economics. 27, 403-417.

Mayer, R. C., Davis, J. H., \& Schoorman, F. D. (1995). An integrative model of organizational trust. Academy of Management Review, 20, 709-734.

McWilliams, A., \& Gray, S. R. (1995). Understanding quasi-integration. Journal of Busjness Strategies. 12, 69-85.

Mehra, A. (1996). Resource and market based determinants of performance in the U.S. banking industry. Strategic Management Journal. 17, 307-322.

Merton, R. K. (1945). Bureaucratic structure and personality. Social Forces, 23, 405-415.

Miles, R. E., \& Snow, C. C. (1994). Fit. failure \& the hall of fame: How companies succeed or fail. New York: Free Press. 
Monteverde, K., \& Teece, D. J. (1982). Supplier switching costs and vertical integration in the automobile industry. Bell Joumal of Economics 13, 206-213.

Nelson, R., \& Winter, S. (1982). An evolutionary theory of economic change. Cambridge, MA: Belknap.

Ouchi, W. G. (1980). Markets, bureaucracies and clans. Administrative Science Ouarterly, $25,129-141$.

Oviatt, B., \& McDougall, P. (1994). Toward a theory of international new ventures. Journal of International Business Studies. 25, 45-64.

Pearce, J. A. (1982). Selecting among alternative grand strategies. California Management Review, 24, 23-31.

Penrose, E. T. (1959). The theory of the growth of the firm. New York: John Wiley.

Peteraf, M. A. (1993). The cornerstones of competitive advantage: A resource-based view. Strategic Management Journal. 14, 179-191.

Pfeffer, J., \& Salancik, G. R. (1982). The external control of organizations: A resource dependence perspective. New York: Harper and Row.

Powell, T. C. (1995). Total quality management as competitive advantage: A review and empirical study. Strategic Management Journal. 16, 15-37.

Prahalad, C. K., \& Hamel, G. (1990). The core competence of the corporation. Harvard Business Review (May-June), 79-91.

Reed, R., \& DeFillippi, R. J. (1990). Causal ambiguity, barriers to imitation, and sustainable competitive advantage. Academy of Management Review. 15, 88-102.

Robins, J., \& Wiersema, M. F. (1995). A resource-based approach to the multibusiness firm: Empirical analysis of portfolio interrelationships and corporate financial performance. Strategic Management Journal. 16, 277-300.

Roth, K., \& O Donnell, S. (1996). Foreign subsidiary compensation strategy: An agency theory perspective. Academy of Management Journal. 39, 678-703.

Russo, M. V. (1991). The multidivisional structure as an enabling device: A longitudinal study of discretionary cash as a strategic resource. Academy of Management Journal. 34, 718-733.

Shane, S. A. (1996). Hybrid organizational arrangements and their implications for firm growth and survival: A study of new franchisors. Academy of Management Journal, 39, 216-234. 
Stroh, L. K., Brett, J. M., Baumann, J. P., \& Reilly, A. H. (1996). Agency theory and variable pay compensation strategies. Academy of Management Journal, 39, 751-767.

Summer, C. E., Bettis, R. A., Duhaime, 1. H., Grant, J. H., Hambrick, D. C., Snow, C. C., \& Zeithaml, C. P. (1990). Doctoral education in the field of business policy and strategy. Journal of Management.16, 361-398.

Teece, D. J. (1980). Economies of scope and the scope of the enterprise. Journal of Economic Behavior and Organization. 1, 223-247.

Teece, D. J. (1987). Profiting from technological innovation: Implications for integration, collaboration, licensing, and public policy. In D. J. Teece (Ed.), The competitive challenge. pp. 185-219. New York: Ballinger.

Venkatraman, N., \& Ramanujam, V. (1986). Measurement of business performance in strategy research: A comparison of approaches. Academy of Management Review, 11, 801-814.

Walker, G., \& Weber, D. (1984). A transaction cost approach to make-or-buy decisions. Administrative Science Quarterly. 29, 373-391.

Wernerfelt, B. (1984). A resource-based view of the firm. Strategic Management Journal, 5, 171-180.

Williamson, O. E. (1975). Markets and hierarchies: Analysis and antitrust implications. New York: Free Press.

Williamson, O. E. (1985). The economic institutions of capitalism; Firms markets, and relational contracting. New York. MacMillan Free Press.

Williamson, O. E. (1991). Comparative economic organization: The analysis of discrete structural alternatives. Administrative Science Ouarterly. 36, 269-296.

Williamson, O. E. (1994). Strategising, economizing, and economic organization. In R. P. Rumelt, D. E. Schendel, \& D. J. Teece (Eds.), Fundamental Issues in Strategy pp. 361-402. Boston: Harvard Business School.

Yip, G. (1982). Diversification entry: Internal development versus acquisition. Strategic Management Journal, 3, 331-345. 
Dr. James G. Combs (Ph.D., Louisiana State University) is an Assistant Professor of Management at the University of Mississippi. His research interests include the resource-based view as a competing theory of the firm and the antecedents to inter-organizational cooperation, especially in the context of franchising. Previous research has been published in the Academy of Management Journal and the Journal of Small Business Management.

Dr. David J. Ketchen, Jr. (Ph.D., Penn State University) is an Assistant Professor of Management at Louisiana State University. His research interests include identifying the determinants of organizational performance, the nature and impact of organizational configurations, and sensemaking processes in organizations. Prior research has appeared in such journals as Academy of Management Journal, Strategic Management Journal, and Journal of Management. 